\title{
The Normative Authority of the World Health Organization
}

Lawrence O. Gostin

Georgetown University Law Center, gostin@law.georgetown.edu

Devi Sridhar

University of Edinburgh

Daniel Hougendobler

Georgetown University Law Center

Available online at: http://www.publichealthjrnl.com/article/S0033-3506(15)00200-0/fulltext

This paper can be downloaded free of charge from:

https://scholarship.law.georgetown.edu/facpub/1498

http://ssrn.com/abstract=2634181

Pub. Health (forthcoming)

This open-access article is brought to you by the Georgetown Law Library. Posted with permission of the author. Follow this and additional works at: https://scholarship.law.georgetown.edu/facpub

Part of the Constitutional Law Commons, Health Law and Policy Commons, Health Policy Commons, Public Health Commons, and the Public Policy Commons 


\title{
Governance for Health Special Issue Paper
}

\section{The normative authority of the World Health Organization $^{\text {th }}$}

\author{
L.O. Gostin ${ }^{a, *}$, D. Sridhar ${ }^{b}$, D. Hougendobler ${ }^{c}$ \\ ${ }^{a}$ Georgetown University Law Center, Law Center, 600 New Jersey Ave., NW, Washington, DC, USA \\ ${ }^{\mathrm{b}}$ Centre for Population Health Sciences, University of Edinburgh, USA \\ ${ }^{\mathrm{c}}$ Georgetown University Law Center, USA
}

\section{A R T I C L E I N F O}

\section{Article history:}

Received 8 April 2013

Received in revised form

1 May 2015

Accepted 2 May 2015

Available online $\mathrm{xxx}$

Keywords:

World Health Organization

Global governance

\begin{abstract}
A B S T R A C T
The World Health Organization (WHO) was born after the devastation of World War II, as a normative agency endowed with unprecedented constitutional powers. But even as it has achieved stunning successes, such as the eradication of smallpox, it has failed to live up to the exalted expectations of the postwar health and human rights movement - exemplified most recently by its inadequate response to the Ebola epidemic. Our aim is to offer innovative ideas for restoring the Organization to its leadership position by exercising its normative authority, even as it faces a crowded and often chaotic global health architecture. Before doing so, it will be helpful to summarize the main tensions the Organization faces in today's global health landscape.
\end{abstract}

(C) 2015 The Authors. Published by Elsevier Ltd. This is an open access article under the CC BY-NC-ND license (http://creativecommons.org/licenses/by-nc-nd/4.0/).

\section{Introduction}

The World Health Organization (WHO) was born after the devastation of World War II, as a normative agency endowed with unprecedented constitutional powers. But even as it has achieved stunning successes, such as the eradication of smallpox, it has failed to live up to the exalted expectations of the postwar health and human rights movement exemplified most recently by its inadequate response to the Ebola epidemic. Our aim is to offer innovative ideas for restoring the Organization to its leadership position by exercising its normative authority, ${ }^{\mathrm{d}}$ even as it faces a crowded and often chaotic global health architecture. We begin by examining the WHO's fundamental tensions and core functions. Next we turn to the Organization's reform agenda, providing an overview of the process and considering six areas in which the WHO is particularly in need of improvement. We conclude with a few reflections on the future of the Organization. Throughout the article, we draw on lessons learned from the response to the recent outbreak of Ebola in West Africa.

\footnotetext{
This article is largely derived from the chapter on the World Health Organization in: Lawrence O. Gostin, Global Health Law. Cambridge: Harvard University Press (2014).

* Corresponding author. Tel.: +1 202662 9038; fax: +1 2026629055.

E-mail address: Gostin@law.georgetown.edu (L.O. Gostin).

d By normative authority, we mean the Organization's power to shape or influence global rules and norms and to monitor compliance. This can be contrasted with, for instance, the Organization's technical role (e.g., providing medical or logistical advice on a vaccination campaign or monitoring and reporting on the global spread of an epidemic).

http://dx.doi.org/10.1016/j.puhe.2015.05.002

0033-3506/@ 2015 The Authors. Published by Elsevier Ltd. This is an open access article under the CC BY-NC-ND license (http:// creativecommons.org/licenses/by-nc-nd/4.0/).
} 


\section{Fundamental tensions}

The WHO, with its unmatched expertise and constitutional mandate, is well positioned to lead a sustained improvement in world health. But the Organization faces critical institutional tensions that significantly impair its functioning: ${ }^{1}$

* A Servant to Member States. Member states demand faithfulness to their often-conflicting demands. They elect the Director-General (D-G), chart the work plan, approve the budget, and steer the overall direction. Such tight control can chill the Secretariat from acting as the moral leader for world health and advocating passionately on behalf of the most disadvantaged;

* A Paucity of Resources. WHO resources are entirely incommensurate with the scope and scale of global health needs. The agency's budget pales in comparison with national health budgets, despite its vast worldwide responsibilities;

* Earmarked Funding. The flow of funds is not only inadequate, but also highly restricted. The agency must have greater authority to direct its resources to where needs are greatest;

* Weak Governance. The WHO lacks critical institutional structures for financial management, transparency, priority setting, and accountability. The Organization also needs to harness the creativity of non-state actors, enable them to fully participate in decision-making, while managing conflicts of interest;

* Excessive Regionalization. Global policies and programs cannot be effectively implemented due to the WHO's decentralized structure. The regions are not fully branches of the Organization, but have wide autonomy. The autonomy of the regions can hamper the WHO's ability to speak with a single voice and exercise global leadership.

\section{Mission and core functions}

The WHO Constitution created a normative institution with extraordinary powers. The Constitution's first Article enunciates a bold mission: 'the attainment by all peoples of the highest possible level of health.' The Preamble defines health as 'a state of complete physical, mental and social well-being and not merely the absence of disease or infirmity.' The Preamble, moreover, places human rights as a central theme, affirming, 'the enjoyment of the highest attainable standard of health is one of the fundamental rights of every human being without distinction of race, religion, political belief, economic or social condition.'

The Constitution unmistakably establishes the WHO as the premier global health leader, stating that it should 'act as the directing and coordinating authority on international health work' - working in close collaboration with UN agencies, national health ministries, and professional organizations (Article 2).

Article 2 grants the WHO extensive normative powers to carry out its mission, authorizing the World Health Assembly (WHA) to adopt 'conventions, agreements and regulations, and make recommendations with respect to international health matters.' The Organization principally exercises its normative authority through 'soft' power - either constitutionally authorized 'recommendations' or more informal action by the Assembly, Board, and/or Secretariat. The Organization rarely exerts its constitutional authority to exercise 'hard' power by negotiating binding international law.

\section{Recommendations: 'soft' global health norms}

The WHO's most salient normative activity has been to create 'soft' standards underpinned by science, ethics, and human rights. Although not binding, soft norms are influential, particularly at the national level where they can be incorporated into legislation, regulation, or guidelines.

Article 23 grants the Assembly the authority 'to make recommendations to Members,' while Article 62 requires states to report annually on the action taken to comply with recommendations. The WHA's two most prominent recommendations are the International Code of Marketing of BreastMilk Substitutes (1981) and the Global Code of Practice on the International Recruitment of Health Personnel (2010).

Apart from these notable exceptions, the Assembly rarely explicitly invokes Article 23. In practice, however, failing to invoke Article 23 appears inconsequential. States are not obliged to comply with recommendations. Moreover, WHO has not enforced Article 62 reporting requirements, rendering the difference between constitutional recommendations and other soft norms less significant.

The WHO uses a variety of legal and policy tools to set soft norms, with varying levels of institutional support. First, the WHA can pass a resolution, which expresses the will of member states, representing the highest level of commitment. Second, the Secretariat can set a standard on a grant of authority from the Assembly or Board, but without the governing authority's formal approval. Finally, the Secretariat can convene expert committees and disseminate their findings without formal endorsement.

The more directly the Assembly approves the normative content, the more likely that member states will support and implement the standard. To build political support for the Organization's most important initiatives, the Assembly adopts a 'request-development-endorsement' process. The WHA, for example, charged the Secretariat with developing both the Breast-Milk Substitutes and Health Personnel Recruitment Codes, followed by formal endorsement. Beyond Article 23 recommendations, the Assembly has placed its full weight behind major Global Strategies, such as on 'Diet, Physical Activity and Health' and on 'The Harmful Use of Alcohol.'

Most soft norms are less formal than full-fledged regulatory texts such as codes of practice or even broad policy frameworks such as global strategies. Given the diverse and complex technical fields within WHO's purview, the Organization has developed a variety of mechanisms for gathering and disseminating expert advice. The Secretariat convenes expert advisory panels and committees to provide technical guidance. $^{2}$ The Expert Committee on Drug Dependence, for example, guides the agency in the discharge of functions assigned under the Single Convention on Narcotic Drugs 
(1961), while the Expert Committee on the Selection and Use of Essential Medicines helps revise WHO's Model List of Essential Medicines. Expert committee reports are advisory but can exert influence on scientific development.

The WHO has established a network of collaborating centers linked to research institutes and universities to support agency functions ranging from nursing, nutrition, and mental health to human rights. The Global Outbreak Alert and Response Network (GOARN) offers another salient example. GOARN is a technical collaboration of institutions that pool human and technical resources for the rapid identification, confirmation, and response to disease outbreaks of international importance.

\section{The negotiation of treaties: hard law}

The WHO Constitution envisages a normative institution that uses law and exercises power to proactively promote the attainment of 'the highest possible level of health.' The WHO's treaty-making powers are extraordinary, with separate processes for the negotiation of 'agreements' or 'conventions' on the one hand and 'regulations' on the other. What makes WHO's law-making powers so special is that the Constitution places affirmative obligations on sovereign states, which is rare in international law. Despite WHO's impressive normative powers, modern international health law is remarkably thin. The WHA has adopted only three treaties in its 65-year history, two of which predate the agency - the Nomenclature Regulations and International Health Regulations.

\section{Conventions or agreements}

Article 19 grants the Health Assembly the power to 'adopt conventions or agreements' by a two-thirds vote. A convention or agreement - binding international treaties - enters into force for each member when the government accepts it in accordance with national constitutional processes.

That much is standard treaty making, as states have unfettered choice. It is Article 20 that is exceptional in that it directs members to 'take action' by accepting or rejecting the convention or agreement within eighteen months after adoption by the Assembly, presumably even if its WHA delegation voted 'no.' Each member must notify the D-G of the action taken, such as submission of the treaty for ratification. If a member does not accede to the treaty within the allotted time, it must furnish a statement of reasons. This is a powerful mechanism, highly unusual in international law, as it requires states to seriously consider the treaty in accordance with national constitutional processes.

Articles 20 and 62 give the D-G monitoring authority, as members that accede to a treaty must report annually towards implementation. More generally, Chapter XIV of the Constitution requires members to report annually on 'action taken' and 'progress' in improving health, as well as to transmit health information at the request of the EB.

The WHO did not negotiate a health convention until 2003, when the Assembly adopted the Framework Convention on Tobacco Control (FCTC). ${ }^{3}$ Although a laudable achievement, the FCTC is almost sui generis because it regulates the only lawful product that is uniformly harmful. The FCTC was politically feasible because the tobacco industry was vilified for obfuscating and denying scientific realities, engineering tobacco to create nicotine dependence, engaging in deceptive advertising, and targeting youth, women, and minorities.

\section{Regulations}

The WHA's quasi-legislative powers under Article 21 empower the Organization to adopt regulations on a broad range of health topics: (a) sanitation, quarantine and other interventions to prevent the international spread of disease; (b) nomenclatures of diseases, causes of death, and public health practice; (c) standards for diagnostic procedures for international use; (d) standards for the safety, purity, and potency of biological and pharmaceutical products moving in international commerce, as well as the advertising and labeling of such products.

The Organization's authority to adopt regulations is even more remarkable than for agreements or conventions. By Article 22, regulations enter into force for all members after due notice is given of WHA adoption, except for members that notify the D-G of rejection or reservations within a specified time. Consequently, states must proactively 'opt out' or they are automatically bound. Perhaps standing alone in international law, the Constitution permits the imposition of binding obligations absent the state's express assent.

Indeed, the regulations may even enter into force for states that notify the D-G of a reservation to the treaty. International law has evolved since the adoption of the WHO Constitution. Under the Vienna Convention and current state practice, reservations that are not incompatible with the overall purpose of the treaty do not preclude a state from being recognized as a party to the treaty.

\section{WHO Regulations No. 1}

The nomenclature rule. Article 2 specifically empowers WHO to establish and revise international nomenclatures of diseases, causes of death, and public health practices, and to standardize diagnostic procedures. The first Assembly in 1948 adopted World Health Regulations No. 1, Nomenclature with Respect to Diseases and Causes of Death, which formalized a long-standing international process on disease classification. By providing standardized nomenclature, the regulation facilitates the international comparison of morbidity and mortality data. The Nomenclature Rule requires states to use the current version of the International Classification of Diseases (ICD), now in its 10th edition, with the 11th Revision planned for 2017.

\section{WHO Regulations No. 2}

The International Health Regulations. The International Health Regulations (IHR), as explained earlier, date back to a series of European sanitary conferences held in the 19th century. The Assembly adopted the International Sanitary Regulations (ISR) in 1951 as WHO Regulations No. 2, covering six quarantinable diseases - cholera, plague, epidemic (louse-borne) typhus, relapsing fever, smallpox, and yellow fever. The 22nd Assembly (1969) revised and consolidated the ISR, which were renamed the IHR. The 26th Assembly (1973) amended the IHR in relation to cholera. The 34th Assembly amended the IHR to exclude smallpox, in view of its global eradication. By the time the 48th Assembly (1995) called for its fundamental revision, the IHR applied only to cholera, plague, and yellow fever - the 
same three diseases discussed at the first Sanitary Conference in 1851 . The Assembly revised the IHR in 2005, which mostly entered into force in 2007.

The WHO's normative powers, therefore, are impressive, obliging sovereign states to submit agreements or conventions to a national political process and informing the Organization of the result. Its regulatory powers are even more farreaching, potentially binding states without the need for formal signing and ratification. States, moreover, have ongoing obligations to report annually on actions taken on recommendations, conventions, and regulations (Art. 62).

\section{'Hard' vs 'soft' norms}

For the most part, the WHO has eschewed norm-setting, preferring scientific and technical solutions to the deep-seated problems of global health. And when it has acted normatively it has mostly chosen 'soft' law in the form of guidelines, codes, or recommendations rather than 'hard' binding international law. Prominent scholars have chastised the WHO for its reluctance to create binding norms, ${ }^{4}$ although this is beginning to change with the FCTC and IHR. Further, there may be good reason for opting for soft instruments, which then U.S. Secretary of State Hillary Clinton called 'smart' power.

\section{National health legislation}

The WHO Constitution underscores the vital interaction between national and international law, with both required for effective promotion of population health. Article 63 directs member states to 'communicate promptly to the Organization important laws, regulations, official reports, and statistics pertaining to health.' The OIHP published excerpts of national public health legislation, which the WHO took over at its inception. ${ }^{6}$

The WHO's International Digest of Health Legislation (IDHL) (Recueil International de Législation Sanitaire) publishes extracts from, and translations of, public health laws and regulations among member states. The Organization, however, has decreased support for this vital constitutional function, both by reducing IDHL staff and discontinuing print publication in 1999. Today, the Digest is available electronically, although it provides only a fragmented and wholly incomplete account of domestic health legislation.

\section{The West African Ebola epidemic: a failure of leadership}

In 2014, one of the WHO's key normative instruments, the International Health Regulations, faced a major test when an outbreak of Ebola began its devastation of West Africa. The treaty - and the Organization - were largely inadequate to the task.

The first case of Ebola in West Africa seems to have appeared in December 2013 in Guinea. By June 2014, the disease had infected more than 500 people and killed at least 337, across 60 separate locations in three countries. ${ }^{7}$ Over the next months Médecins Sans Frontières, one of the few organizations providing on-the-ground support, issued increasingly urgent calls for a concerted international response. ${ }^{7}$ Nevertheless, it took until August 8, more than four months after the first international spread was first detected and long past the point where the epidemic had spun out of control, for the WHO to declare the epidemic a public health emergency of international concern (PHEIC), thus triggering obligations under the IHR. ${ }^{8} \mathrm{Ul}-$ timately it was the United Nations that led the global response, with an unprecedented Security Council resolution and a UN Mission. ${ }^{9}$ To date, the epidemic has killed over 10,000 people, nearly all in Guinea, Liberia, and Sierra Leone.

The Ebola epidemic presented an important test of the IHR, revealing flaws in the regulations and in the WHO more broadly. The declaration of a PHEIC took too long, and domestic public health capacity was grossly inadequate (despite IHR requirements), revealing a failure in global cooperation to develop these capacities. When the global response did finally begin in earnest, it suffered from a lack of clear leadership. ${ }^{10}$

To WHO's credit, it has acknowledged some flaws in its response. It has solicited an independent assessment of its efforts and its Executive Board (EB) held a special session on Ebola during which it renewed calls for reform. ${ }^{11}$ In addition, four major reforms were agreed at the 2015 WHA: combining WHO's outbreak and emergency response programs; creating a \$100 million contingency fund; developing a global health emergency workforce; and launching an overhaul of the IHR. In the next section, we discuss the WHO's reform agenda and how a reformed WHO might be better equipped to respond the next infectious disease epidemic, as well as to other threats to global health.

\section{The WHO's reform agenda}

On March 10, 2011, the day before convening the D-G's Ad Hoc Advisory Committee on Reforming the WHO, Margaret Chan called together all staff at Headquarters, with regional staff joining by satellite. She announced an alarming budget deficit and staff lay-offs, calling for fundamental reform. That May, the Assembly endorsed the reform agenda, while the EB launched 'a transparent member state-driven and inclusive consultative process on WHO reform. ${ }^{12}$

In 2012, the WHA and EB defined three reform objectives: (1) improved health outcomes, with the WHO setting priorities agreed by member states and partners; (2) greater coherence in global health, with the WHO playing a leading role in enabling multiple actors to become more effective; and (3) pursing excellence that is effective, efficient, responsive, objective, transparent, and accountable. ${ }^{13}$

The reform agenda reveals keen self-awareness of the challenges, but why hasn't the agency been able to fully succeed? Why are so many allies concerned about the Organization's future? Why has it been so hard for the agency to change and adapt? We conclude this paper with proposals to ensure that the WHO can reclaim its rightful place as the world's premier health organization. ${ }^{14,15}$

\section{Exercise WHO's legal authority}

As explained above, the WHO was formed as a normative institution, charged with directing and coordinating global health activities. The justification for norm-creation is not 
simply that it is constitutionally mandated, but also that it will drive change far better than scientific and technical support alone. Norm development can set the global health agenda, guide priorities, harmonize activities, and influence the behavior of key state and non-state actors.

If the WHO is to reassert its constitutional authority as a normative institution, then what principles should it adopt? What is the most effective combination of hard and soft norms? And how can it facilitate implementation of, and compliance with, health norms?

\section{Human rights and global justice}

The WHO's history and constitutional design point to human rights as a primary source for norm development. What is striking about the postwar consensus is that the United Nations envisaged health and human rights as two great, intertwined social movements, with the UN Charter, Universal Declaration of Human Rights, and the WHO Constitution as the defining instruments. The first two sentences of the Constitution's Preamble define health expansively and proclaim 'the highest attainable standard of health' as a fundamental human right. The WHO was supposed to be the vanguard of the right to health.

Yet despite notable achievements, the Organization has been reticent to venture into norm-development, and rarely invokes the right to health. It certainly has not been a leader in the health and human rights movement, leaving that space to civil society and the UN Special Rapporteur on the right to health. The Assembly in 65 years has not passed a single resolution on the right to health. Exemplifying states' reluctance, the U.S., in 2008, strenuously objected to an innocuous WHO/Office of the High Commissioner for Human Rights fact sheet on the right to health, emphasizing 'the seriousness of our concerns' and reiterating 'our request that it be rescinded.' 16

\section{'Soft' and 'hard' norms}

The WHO has rarely exercised its law-making powers, negotiating only two major treaties - the International Health Regulations and the Framework Convention on Tobacco Control. This represents a missed opportunity, as law can be a powerful public health tool. Just as tobacco and health security transcend borders justifying the FCTC and IHR, so too do a range of major health hazards, such as non-communicable diseases, mental illness, and injuries.

Soft norms complement international law - a fact that the WHO increasingly realizes with codes of practice, action plans, and global strategies. States are more likely to buy into expansive standards if they are not legally bound, providing the WHO with an opportunity to issue bold guidance on highly consequential issues, such as health systems, access to essential medicines, and socio-economic determinants. The Organization could go beyond declarations, reports, and commissions by negotiating normative standards for adoption by state and non-state actors. Soft instruments, moreover, can become the building blocks for subsequent treaties, with greater enforcement and accountability.

Legal agreements could have made for a stronger and more efficient response to Ebola. An agreement on the equitable sharing of drugs and other therapies could guide fairer distribution of scarce experimental drugs, an issue of significant concern during the outbreak. (The Organization does have one such agreement, the Pandemic Influenza Preparedness Framework, but it applies only narrowly.) A biomedical research and development agreement could accelerate the development of safe and effective treatments and vaccines, particularly for neglected diseases like Ebola. And a broad global health convention, grounded in the principles of human rights and universal health coverage, can ready countries' health systems to cope with the strain of epidemic disease. ${ }^{17}$

\section{Implementation and compliance}

If norms are to have 'bite,' they must include effective mechanisms for accountability. Although WHO's comparative advantage is not in policing, the agency is well constituted for convening, monitoring, and reporting. The convening process itself could lay the groundwork for gaining stakeholder 'buyin.' Once the normative instrument is adopted, ongoing monitoring could provide a 'feedback loop,' with actors reporting on progress. The lack of capacity in developing countries remains a key challenge, requiring innovative financing and technical assistance.

Traditionally, international instruments have been directed primarily at states, leaving out multiple stakeholders. Extending normative influence to businesses, foundations, the media, and civil society could help ensure compliance. Advocates could exert political influence and rally public opinion. For example, NGOs could issue 'shadow reports,' holding stakeholders to account for failing to live up to their promises.

The all-of-society approach

The 'all-of-government' or 'health-in-all-policies' (HiAP) approach recognizes that ministries of health cannot accomplish major reforms on their own. HiAP urges all government departments to take health into account in their policies and practices. Beyond governments, an 'all-of-society' approach seeks to include all social sectors to achieve meaningful results, such as businesses, foundations, the media, and academia.

\section{Members must become shareholders}

During the Ad Hoc Advisory Committee on Reforming the WHO, the D-G said something telling, and brave. ${ }^{18}$ She observed that member states do not behave as 'shareholders' with a genuine stake in the Organization's success. That critique has a ring of truth. States, of course, do want the agency to succeed, but they act in ways that thwart effective action (a problem that is hardly unique to the WHO).$^{19} \mathrm{Mem}$ bers want the WHO to be adequately funded, with control over its finances. Nevertheless, they resist higher mandatory assessments, push unfunded mandates, and some are in arrears in paying their dues.

Members want the WHO to exert leadership, harmonize disparate activities, and set priorities. Yet they resist intrusions into their sovereignty, and want to exert control. In other words, 'everyone desires coordination, but no one wants to be coordinated.' States often ardently defend their geostrategic interests. As the Indonesian virus-sharing episode illustrates, the WHO is pulled between power blocs, 
with North America and Europe (the primary funders) on one side and emerging economies such as Brazil, China, and India on the other. An inherent tension exists between richer 'net contributor' states and poorer 'net recipient' states, with the former seeking smaller WHO budgets and the latter larger budgets.

Overall, national politics drive self-interest, with states resisting externally imposed obligations for funding and action. Some political leaders express antipathy to, even distrust of, UN institutions, viewing them as bureaucratic and inefficient. In this political environment, it is unsurprising that members fail to act as shareholders.

Ebola placed into stark relief the failure of the international community to increase capacities as required by the IHR. Guinea, Liberia and Sierra Leone had some of the world's weakest health systems, with little capacity to either monitor or respond to the Ebola epidemic. ${ }^{20}$ This caused enormous suffering in West Africa and placed countries throughout the region - and the world - at risk. Member states should recognize that the health of their citizens depends on strengthening others' capacity. The WHO has a central role in creating systems to facilitate and encourage such cooperation.

The WHO cannot succeed unless members act as shareholders, foregoing a measure of sovereignty for the global common good. It is in all states' interests to have a strong global health leader, safeguarding health security, building health systems, and reducing health inequalities. But that will not happen unless members fund the Organization generously, grant it authority and flexibility, and hold it accountable.

\section{Ensure predictable, Flexible, and adequate funding}

By its own admission, the WHO is 'over-extended and overcommitted,' with insufficient resources to meet expanding needs, and resources not fully within its control. ${ }^{21}$ The Global Fund, U.S. Global Health Initiative, and the Bill \& Melinda Gates Foundation overshadow the $\$ 4.17$ billion budget that the D-G proposed for 2016/17. The U.S. Centers for Disease Control and Prevention has more than three times the budget of the entire WHO. ${ }^{22}$

The agency ran a budget deficit of at least $\$ 300$ million in 2010/11. To close the deficit, members set the WHO's 2012/13 budget at $\$ 3.96$ billion - nearly $\$ 1$ billion less than the D-G sought, with 300 headquarters staff members $(>10 \%$ of personnel) losing their jobs. Despite a quadrupling of global health funding for the decade ending in 2010, and a doubling of the WHO's budget, the agency finds itself in crisis. A combination of unfunded mandates from its members, growing health challenges, a long-term rise in the value of the Swiss Franc, and poor fiscal control all contributed to the current predicament. The global economic downturn will only place greater pressure on WHO funding levels, virtually flat lined in the 2016/17 budget proposal. Such budget cuts severely undermined WHO's ability to respond to the Ebola epidemic. For example, the section of WHO that manages emergency response was 'whittled to the bone' - reduced from 94 staff to just 34 - due to budget constraints. ${ }^{23}$

The WHO's financing structure derives from two main streams. The first is 'assessed contributions' to cover part of its budget, the costs of which are apportioned among members according to each country's wealth and population. The assessed contribution levels appear to be more a function of political will than a careful assessment of actual global need. The second stream, 'extra-budgetary funding,' is sourced from voluntary contributions by member states and private funders, and is often earmarked for specific diseases, sectors, or countries.

The agency's dire financial position is not due solely to insufficient funds, but also to its lack of flexibility in spending resources. In 1998/99, 48.8\% of its budget was from discretionary sources - the voluntary funds - while today it has grown to nearly $80 \% .{ }^{24}$ This $80 / 20$ split undermines the Organization's effectiveness and flexibility to meet rapidly changing health threats.

Having voluntary funding represent such a disproportionate amount of the agency's total budget is untenable. Extra-budgetary funding has transformed the WHO into a donor-driven organization, restricting its ability to direct and coordinate the global health agenda. The rationale for the shift towards extra-budgetary funding is clear: by tying funding to specific programs, donors ensure that their resources influence the activities and direction of the organization. Donor preferences often change from year to year, impeding longer-term strategic planning and capacity building.

Extra-budgetary funding, moreover, skews global health priorities. Assessed contributions are more aligned with the actual global burden of disease than extra-budgetary funding. For example, in 2010/11 the WHO's extra-budgetary funding was primarily for infectious diseases $(65 \%)$, with negligible allocations for non-communicable diseases (NCDs) and injuries. Yet, NCDs account for $65 \%$ of all deaths worldwide, and injuries $11 \%$ of the global burden of disease. ${ }^{25}$

The WHO's reform agenda proposes broadening the funding base by attracting donations from foundations, emerging economies, and the private sector. Although worthwhile, these stakeholders are unlikely to behave differently than traditional donors, and will prefer to control their funds through earmarks. Reliance on philanthropic and corporate funding, moreover, opens the agency to the charge that it is not fully independent.

To increase WHO control over its budget and better align financing with organizational priorities, the 2013 WHA gave itself the power to approve the budget in its entirety, rather than only the portion funded by assessed contributions. A financing dialog, concluded in 2014, aimed to increase predictability and alignment of WHO's financing with the Organization's program of work. It, along with more realistic budgeting, was designed to reduce the impact of drastic fluctuations in voluntary allocations, while trying curtail the ability of individual donors to sway WHO's agenda through earmarked contributions. The dialog's final report offered a series of recommendations, most of which the Organization has not yet implemented. ${ }^{26}$

The ideal solution to donor-driven priorities should go beyond these reforms, and would be for the WHA to set higher member contributions. The Assembly should commit to increasing assessed contributions so that within five years mandatory dues comprise at least $50 \%$ of the overall budget, 
along with a top-to-bottom budget review to match WHO's budget to global health needs and WHO's functions. ${ }^{27} \mathrm{Mem}$ bers could also give untied voluntary contributions above their assessed dues and provide longer-term commitments. Member states must become genuine shareholders in the WHO's future, act collectively, and refrain from exerting narrow political interests. Failing decisive WHA action, the WHO could consider charging overheads of $30-50 \%$ for voluntary contributions to supplement its core budget. Although overheads are a familiar model in academia, the WHO would have to guard against the risk that charges might drive donors toward other agencies. Whatever the formula, there is little doubt that the WHO will never reach its potential unless members ensure that financing is predictable, sustainable, and scalable to global health needs.

\section{Improve WHO governance: transparency, effectiveness, and accountability}

As a member-owned intergovernmental agency, the WHO must be open to scrutiny, with its evidence, reasons, and dealings with outside parties plainly disclosed. Disclosure is a necessary but not sufficient condition of sound governance, as the WHO must also competently manage potential conflicts of interest, both financial and non-pecuniary. Most importantly, good governance requires tangible results with clear targets and plans for their achievement. The D-G's proposal for a 'results-chain' - standard indicators to measure outputs and impact - is an important step. The WHO's proposed 2016-2017 budget included numerical indicators for each program area and deliverables at country, regional, and headquarter levels. ${ }^{28}$

In the aftermath of the Influenza A (H1N1) pandemic, an independent IHR review committee suggested establishing a $\$ 100$ million reserve fund for public-health emergencies as well as an emergency workforce that could be deployed quickly in case of an epidemic. ${ }^{1}$ Neither was implemented. Commissioning reports is only the first step to accountability. WHO must also follow through on recommendations and adjust in response to past failings. Had the Organization followed the recommendations of the H1N1 Review Committee, the response to the Ebola epidemic would likely have been quicker, less costly, and more effective. Following the January 2015 Executive Board resolution, WHO now seems committed to implementing versions of both these recommendations.

Stakeholders demand clarity on how their resources will achieve improved health outcomes. Yet, an independent evaluation graded WHO as 'weak' on key parameters, such as cost-consciousness, financial management, public disclosure, and achievement of development objectives. ${ }^{29}$ The reform agenda promised to establish independent evaluations of the WHO's work. ${ }^{30}$

\section{Harnessing the energy and power of non-state actors}

As a UN agency, the WHO is comprised solely of member states, which govern through the Assembly and Executive Board. This governing structure affords the WHO legitimacy and influence, standing alone as the voice of the community of nations in global health. Yet, this state-centric focus often sidelines valuable stakeholders - public, private, and philanthropic.

If non-state actors are not given a voice in the WHO, they will redirect their energies elsewhere. This process has been gradually 'hollowing out' WHO, as resources and influence move to bilateral programs (e.g., PEPFAR), innovative partnerships (e.g., Global Fund and GAVI Alliance), and foundations (e.g., the Gates Foundation).

NGOs' lack of voice may also lead to poorer decision making. For instance, had WHO given greater heed to MSF's consistent and unequivocal calls for a strong response to the West African Ebola epidemic the disease might have been stopped before it spun out of control. Failing to provide an effective participatory forum for those on the ground impoverishes global dialogue and risks decisions being made on the basis of an incomplete picture.

Beyond major competing institutions lies a world with numerous stakeholders. Many of these actors have become disillusioned with the WHO, feeling that the Organization has not heard their voices and reflected their interests. A major function of leadership is to harness the resources and energy of key stakeholders. The distant and sometimes distrustful relationship between the WHO and non-state actors could be changed, to enlist stakeholders in a strategic alliance.

Non-state actors play no formal role in WHO governing structures. The Assembly and Board do not fully recognize stakeholders beyond states. This contrasts with UNAIDS, which includes civil society on its governing board, although with non-voting status. More recent partnerships, like the Global Fund and GAVI Alliance, seat civil society, businesses, and foundations as voting board members.

\section{Multi stakeholder engagement}

Currently, there is no single platform for dialogue among international organizations, states, partnerships, foundations, businesses, and civil society. The WHO would be more effective by giving voice and representation to stakeholders. To achieve this goal, the D-G proposed a World Health Forum in 2011 multi stakeholder meetings under WHO auspices to increase effectiveness, coherence, and accountability, and reporting to formal governing structures. ${ }^{31}$ States, however, rejected the Forum, while civil society feared it would advance corporate interests. In its stead, the D-G proposed: stakeholder forums targeted to key policies, separate consultations with different constituencies, and web-based and in-person meetings.

To be effective, these proposals must influence the WHO's agenda, priorities, and governing structures. For example, the agency could create a meaningful platform for developing an innovative 'Framework for Global Health,' adopted by the Executive Board and Assembly, monitored by civil society, and with genuine accountability mechanisms. ${ }^{32}$

Whatever the ultimate forms of engagement, they must be fair and inclusive, ensuring voice for marginalized communities and resources to enable civil society participation. ${ }^{33}$ This requires transparent and representative selection processes, with agreed action agendas. And it requires proactive outreach to disadvantaged communities least likely to be aware of or have the means to participate. Without a commitment to inclusion, civil society may be marginalized, with the private sector dominating. 


\section{Official NGO status}

The WHO makes it very difficult for NGOs to gain 'Official Relations' status, which is prerequisite for non-voting participation in WHO meetings. NGOs with this status may attend Executive Board and Assembly sessions and make prepared (but not extemporaneous) statements.

With limited exceptions, to enter into official relations, an NGO: (i) must be international, representing 'a substantial proportion of the persons globally organized' in the field, (ii) must have a constitution, governing body, and administrative structure, with a voting membership, and (iii) must have major activities relevant to the WHO's 'health-for-all' strategy. Even then, most NGOs must have two years of informal relations prior to applying for admission into official relations. ${ }^{34}$ This burdensome process often excludes NGOs that are domestic, poorly funded, small, or have a specific mission-even if they are influential. Currently, most NGOs in official relations are Northern-based. ${ }^{35}$

The Executive Board and Assembly should lower the bar to NGO participation, and be more welcoming of civil society. It could offer scholarships to developing country NGOs to participate. And it could expand opportunities for civil society input, such as by allowing extemporaneous statements, facilitating NGO side sessions, and conducting open hearings. In 2004, the Assembly postponed for 'further study' a proposal to simplify the process for non-state participation. ${ }^{36}$ The proposal is still pending with little prospect of success.

\section{World Health Assembly 'Committee C.'}

Scholars and diplomats have proposed a WHA Committee C comprised of major stakeholders, such as international organizations, foundations, multinational health initiatives, and civil society. ${ }^{37}$ The objectives are to increase transparency, coordination, and engagement of stakeholders. The two extant WHA Committees are comprised solely of states, and their business is concerned mostly with governance and financing of the agency. Yet, the Assembly's mandate extends beyond the WHO, granting authority to 'direct and coordinate' global health activities, while also collaborating with specialized agencies, governments, professional groups, and other actors (Art. 2).

The Constitution grants the Assembly power to establish additional committees, and to invite non-voting representatives (Art. 18). A Committee $\mathrm{C}$ would debate health initiatives, give stakeholders a venue to present their activities and plans, and discuss harmonization of activities.

\section{Conflicts of interest}

Conflict of interest is a vital ethical concern for WHO governance, as perceptions of probity underpin the confidence others bestow on the Organization. The WHO must be careful to ensure that cooperating entities are genuinely devoted to the public interest, without pecuniary or other competing interests. ${ }^{38}$ Although true for all groups, it is especially pertinent when engaging the private sector, such as the food, alcoholic beverage, pharmaceutical, and biotechnology industries. (The WHO already has strict rules to exclude tobacco companies or those funded by them.) The WHO has a duty to set and oversee health and safety standards for businesses, which is another reason not to grant them privileged access. For example, it would be inappropriate for the food or marketing industries to fund nutrition guidelines. Contributors finance areas of their own interest, and companies may profit by influencing WHO decision-making. The Executive Board should design a clear, transparent process for managing conflicts, including monitoring and enforcement.

Although foundations do not have the same potential for conflicts as the private sector, they can still exercise considerable influence. Wealthy philanthropists such as Bill Gates and Michael Bloomberg donate vast resources, but they can also skew the world health agenda. For example, the Gates Foundation and other undisclosed sources helped fund the WHO blueprint for reform, raising the question of whether there is sufficient separation between the interests of the WHO and wealthy donors, which are not fully transparent or accountable.

\section{Staffing: from technical excellence to global leadership}

The Secretariat has evolved a culture of technical excellence and country-level support, comprised of gifted scientists, epidemiologists, and physicians. As vital as these functions are, global leadership requires much more, such as setting priorities, harmonizing fragmented activities, and influencing stakeholders - all complex and difficult challenges.

The reform agenda stresses human capital, which is at the heart of the WHO's strength and credibility. The promise of better recruitment and retention, however, omits two critical problems. First, the Organization's financial crisis prompted a major downsizing of personnel, and it is unclear how current staff levels can meet the burgeoning health challenges facing the agency. Without a major influx of resources, the Secretariat can neither expand nor even retain highly professional staff.

Second, the reform fails to tackle the kinds of human resources needed in a modern globalized world. In addition to scientific excellence, the WHO needs highly accomplished lawyers, diplomats, mediators, and economists, as well as experts in trade, intellectual property, human rights, and other disciplines. Although the WHO does have staff with such skills (e.g., the General Counsel's Office, the International Health Regulations, and human rights), they are not broadly represented across the agency.

The Organization's reluctance to develop norms may well be because it lacks the requisite funding and expertise, and does not see its comparative advantage over other UN institutions. Yet, that is a design choice in setting its agenda, allocating its resources, and developing its workforce. It is not reflected in the WHO's constitutional mandate.

\section{Toward a healthy future}

The West African Ebola epidemic highlights some of the systemic problems plaguing the WHO. The failure of one of Organization's signature treaties (the IHR) illustrates the Organization's institutional weakness as well as the failure of states to comply with their obligations. Too little, and excessively earmarked, funding undermined the response to the epidemic by reducing the organization's ability to adapt to new priorities. And the WHO's own internal decisions on such 
issues as civil society engagement made it harder for individuals and organizations on the ground to be heard.

Political support is essential to overcome formidable barriers to change. While the G8 previously dominated, today the G20 could become transformative. Emerging powers such as Brazil, India, and South Africa have interests that diverge from the neoliberal model. They could demand a new deal perhaps a 'Bretton Woods II' accord for global health. ${ }^{39}$ Nearly 70 years ago in Bretton Woods, the world's powers formed the World Bank Group. Today, a different set of powerful actors could place health and development at the center of global governance.

Achieving the necessary political support will require more than a shifting set of actors, however. In some respects, epidemic response, and emergency preparedness more generally, are the low-hanging fruit, for which the benefits to member states are most evident - and the necessity of international cooperation is the clearest. Empowering the WHO to address more systemic global health needs, e.g., universal health coverage, will require politicians to elevate health to a higher priority. Further it will require a popular understanding of health (and not just infectious disease) as a global public good rather than as a purely domestic matter. This will only be achieved if leaders can effectively engage civil society, the private sector, governments and individuals. Overcoming the global system's current inertia will not be easy, but it could pay extraordinary dividends.

Despite progress, serious questions remain about whether the WHO reform process will make a meaningful difference. While the WHO established measurable programmatic targets and took measures to align its funding with priorities, assessed contributions in the 2016/17 budget were unchanged from the previous budget. The Organization's revised framework of engagement with non-state actors presented to the Executive Board in January focuses on institutional integrity, necessary to build trust. Yet it avoids fundamental reform on engaging civil society. ${ }^{40}$

Yet if it is to hold its rightful place as the global health leader, including positioning itself to respond effectively to the next epidemic, WHO must undergo fundamental reform. Member states hold the future of the WHO in their hands. If they invest in and support the Organization, it would pay dividends in health security and human well-being. The WHO's current malaise can be overcome. Members would guarantee its future by acting as shareholders; the Secretariat would govern itself well, while exercising normative influence within and beyond the health sector; the governing bodies would actively engage stakeholders; and the Assembly would ensure the resources and flexibility needed to meet evolving health challenges.

\section{Author statements}

\section{Ethical approval}

None sought.

\section{Funding}

None declared.

\section{Competing interests}

None declared.

\section{R E F E R E N C E S}

1. World Health Organization Implementation of the International Health Regulations. Report of the review committee on the functioning of the international health regulations. 2011 May 5. Document No.: A64/10; 2005.

2. World Health Organization. Regulations for expert advisory panels and committees; 2000 May 20. Resolution No: WHA53.10.

3. World Health Organization. Framework convention on tobacco control; 2003 May 21. Document No: A56/VR/4.

4. Taylor AL. Making the World Health Organization work: a legal framework for universal access to the conditions for health. Am J Med Health 1996;18(4):301-46. Fidler D. The Future of the World Health Organization: What role for international law. Vanderbilt J Transn Law 1998;31(5):10791126.

5. Naughton P. Hillary Clinton says 'smart power' will restore American leadership. Times (UK). Available from: http://www. thetimes.co.uk/tto/news/world/americas/article1999131.ece; 2009 Jan 13.

6. Tobey JA. Review of international digest of health legislation. Vol. 1, No. 1. Am J Public Health Nations Health 1949;39(11):1484.

7. Médecins Sans Frontières. Ebola in West Africa: epidemic requires massive deployment of resources. Press release. 2014 Jun 21. Available from: http://www.msf.org/article/ebolawest-africa-epidemic-requires-massive-deploymentresources.

8. World Health Organization. Statement on the 1st meeting of the IHR Emergency Committee on the 2014 Ebola outbreak in West Africa. Press release. 2014 Aug 8. Available from: http:// www.who.int/mediacentre/news/statements/2014/ebola20140808/en/.

9. United Nations General Assembly. Measure to contain and combat the recent Ebola outbreak in West Africa. Resolution No: A/RES/69/1. United Nations Security Council; 2014 Sep 23. Resolution No: S/Res/2177. 2014 Sep. 18.

10. Gostin LO, Friedman E. Ebola: a crisis in global health leadership. Lancet 2014;384(9951):1323-5.

11. World Health Organization Executive Board. Ebola: ending the current outbreak, strengthening global preparedness and ensuring WHO's capacity to prepare for and respond to future large-scale outbreaks and emergencies with health consequences. Resolution No: EBSS3.R1. Available from: http://apps.who.int/gb/ebwha/ pdf_files/EBSS3/EBSS3_R1-en.pdf; 25 Jan 2015.

12. World Health Organization. The future of financing for WHO. Resolution No: A64/4; 2011 May 5. WHO reforms for a healthy future. Resolution No: EBSS/2/2. 2011 Oct 15.

13. US General Accountability Office. World Health Organization reform agenda developed, but U.S. actions to monitor progress could be enhanced. Document No: GAO-12-722 Jul 2012;2012 [Recommending an assessment tool to monitor WHO progress on transparency and accountability)].

14. Gostin LO. Global health law. Cambridge (MA): Harvard University Press; 2014. Sridhar D, Gostin LO. Reforming the World Health Organization. JAMA. 2011 Apr 20;305(15):1585-86.

15. Sridhar D, Gostin LO. Reforming the world health organization. JAMA 2011 Apr 20;305(15):1585-6.

16. Observations of the United States of america on the 'Right to health, fact sheet No. 31.' Available from: http://www.state. gov/documents/organization/138850.pdf. 
17. Gostin LO. A Framework Convention on global Health: health for all, justice for all. JAMA 2012 May 16;307(19):2087-92.

18. Chan M. Ad hoc advisory committee on reforming the WHO. Speech; 2011 Mar 11.

19. Hale T, Held D, Young K. Gridlock: why global cooperation is failing when we need it most. Oxford (UK): Polity; 2013.

20. McNeil DG. Ebola-stricken countries lagged in health systems. NY Times: D7; 2015 Mar 10.

21. World Health Organization. Reforms for a healthy future. Resolution No: A64/4; 2011 May 5.

22. World Health Organization Executive Board. Proposed programme budget 2016-2017. Document No: EB136/34. Centers for Diseaes Control and Prevention. Overview of the budget request. Available from:, http://www.cdc.gov/injury/pdfs/ budget/cdc_fy2016_pb_overview_table.pdf; 2015 Jan 16.

23. Fink S. Cuts at WHO hurt response to Ebola crisis. NY Times; 2014 Sep 4.

24. World Health Organization. Medium-term strategic plan 2008-2013. Resolution No.: A60/11; 2007 may 21 (Amended draft submitted january 2009). World Health Organization. Proposed programme budget 2014-2015, Resolution No.: A66/ 7. 2013 Apr 19. (77\% voluntary contributions). Sridhar D, Woods N. Trojan multilateralism: global cooperation in health. Global Policy. 2013 Nov.;4(4):325-335.

25. Lozano R, Naghanvi M, Foreman K, Lim S, Shibuya K, Aboyans V. Global and regional mortality from 235 causes of death for 20 age groups in 1990 and 2010: a systematic analysis for the global Burden of Disease Study. Lancet 2012 Dec 15;380(9859):2095-128. Lancet. Christopher J.L. Murray et al., 'Disability-adjusted life years (DALYs) for 291 diseases and injuries in 21 regions, 1990-2010: A systematic analysis for the Global Burden of Disease Study 2010. Lancet. 2012 Dec 15;380(9859):2197-223.

26. World Health Organization. WHO financing dialogue evaluation: final report. Available from: http://www.who.int/about/ resources_planning/financing_dialogue/FD_ EvaluationFinalReport.pdf; 2014 Apr 17.

27. Gostin LO, Friedman EA. A retrospective and prospective analysis of the West African Ebola virus disease epidemic: robust national health systems at the foundation and an empowered WHO at the apex. JAMA 2015. May 9;385(9980):1902-9.

28. World Health Organization. Proposed programme budget 20162017; 2015 Jan 16. Document No.: EB136/34.

29. UK Department for International Development. Multilateral aid review: ensuring maximum value for money for UK aid through multilateral organizations. Available from: https://www.gov.uk/ government/uploads/system/uploads/attachment_data/file/ 67583/multilateral_aid_review.pdf; 2011 March.

30. World Health Organization. Independent formative evaluation of the World Health Organization: concept paper. Available from: http://www.who.int/dg/reform/en_who_reform_evaluation. pdf; 2011 June 22.
31. World Health Organization. World health forum: concept paper. Available from: http://www.who.int/dg/reform/en_who_ reform_world_health_forum.pdf; June 22, 2011.

32. World Health Organization. WHO reform for a healthy future: an overview. Available from: http://www.who.int/dg/reform/en who_reform_overview.pdf; 2011 Jul 20. World Health Organization Executive Board. WHO reforms for a healthy future. Document No: EBSS 2/2. Available from: http:// apps.who.int/gb/ebwha/pdf_files/EBSS/EBSS2_2-en.pdf.

33. Friedman EA. World health assembly 2011 outcomes and united nations AIDS review preview. O'Neill Institute Blog [Internet]. Available from: http://www.oneillinstituteblog.org/ world-health-assembly-2011-outcomes-and-united-nationsaids-review-preview/; Democratizing Global Health Coalition to Permanent Missions to the United Nations Office. Concept papers on the WHO reform process. 2011 June 30. Available from: https://docs.google.com/document/d/ 1MshgM45Yt1OJ1KovNbjCVWkqIAxkizh-k1HVsEVR8NM/edit.

34. World Health Organization [Internet]. Principles governing relations with nongovernmental organizations. Available from: http://www.who.int/civilsociety/relations/principles/ en/; 2015 Mar 23.

35. Lanord C. A study of WHO's official relations system with nongovernmental organizations. World Health Organization. Document No: CSI/2002/WP4. Available from:: http://www. who.int/civilsociety/documents/en/study.pdf; Schwarz T. A stronger voice for civil society at the World Health Assembly? Medicus Mundi International Network [Internet] [updated 2013 Feb 4; cited 2015 Mar 23]. Available from: http:// www.medicusmundi.org/en/contributions/reports/2010/astronger-voice-of-civil-society-at-the-world-healthassembly.

36. World Health Organization. Policy for relations with nongovernmental organizations: Note by the Director-General; 2004 Apr 1. Document No.: WHA57/32; World Health Organization [Internet]. Status of proposal for a new policy to guide WHO's relations with NGOs [cited 2015 Mar 23]. http://www.who.int/ civilsociety/relations/new_policy/en/.

37. Silberschmidt G, Matheson D, Kickbusch I. Creating a committee C of the World Health Assembly. Lancet 2008;371(9623):1483-6.

38. Stuckler D, Basu S, McKee M. Global health philanthropy and institutional relationships: how should conflicts of interest be addressed? PLoS Med 2011;8(4):e1001020.

39. Dybul M, Piot P, Frenk J. Reshaping global health. Policy Rev::173. Available from: http://www.hoover.org/ publications/policy-review/article/118116; 2012.

40. World Health Organization Executive Board. Framework of engagement with non-state actors. Document No: EB136/5; 2014 Dec. 15. 